\title{
Production and Characterization of Eco Enzyme Produced from Fruit and Vegetable Wastes and its Influence on the Aquaculture Sludge
}

\author{
Olgalizia Galintin ${ }^{1}$, Nazaitulshila Rasit 1,*(D), Sofiah Hamzah ${ }^{1(D)}$ \\ 1 Faculty of Ocean Engineering Technology and Informatics, Universiti Malaysia Terengganu, Kuala Nerus 21030, \\ Terengganu \\ * Correspondence: nazaitulshila@umt.edu.my;
}

Scopus Author ID 56516956900

Received: 18.09.2020; Revised: 10.10.2020; Accepted: 11.10.2020; Published: 14.10.2020

\begin{abstract}
The high composition of food waste in municipal solid waste production is one of the most critical environmental issues since the decomposition process produces and releases carbon dioxide and methane into the atmosphere and causes a greenhouse effect. Therefore, to minimize the composition of organic wastes in the landfill, this study was conducted to characterize the eco enzyme produced from the fermentation of fruit waste. Then, the treatment of aquaculture sludge will also be determined to examine its applicability. The effectiveness of the eco enzyme on sludge treatment was experimented based on the different dilution factors of the eco enzyme $(5 \%, 10 \%, 15 \%)$ for 10 days (Batch process). The results showed that the eco enzyme possesses Protease, Amylase, and Lipase. Meanwhile, the results of the treatment process showed the enzyme solution (10\%) was found more potent and economical in treating aquaculture sludge in which resulted in a reduction of $89 \%$ of Total Suspended Solid, $78 \%$ of Volatile Suspended Solid, $88 \%$ of Chemical Oxygen Demand, $94 \%$ of Total Ammonia Nitrogen and $97 \%$ of Total Phosphorus. Eco enzyme produced from the study has effectively acted as an environmentally friendly solution to reduce the composition of food waste in solid waste generation and has the potential to be applied in the wastewater industry.
\end{abstract}

Keywords: eco enzyme; aquaculture sludge; fruit and vegetable wastes.

(C) 2020 by the authors. This article is an open-access article distributed under the terms and conditions of the Creative Commons Attribution (CC BY) license (https://creativecommons.org/licenses/by/4.0/).

\section{Introduction}

Malaysia's population has been growing rapidly and leading to a massive amount of waste production. The municipal solid waste composition in Malaysia is about $45 \%$ of which is food waste, and less than $5 \%$ of the food waste is being recycled [1]. The average amount of waste generated in 2003 was $0.5-0.8 \mathrm{~kg} /$ person/day and currently has escalated to 1.7 $\mathrm{kg} /$ person/day; and as a result, higher cost and critical management of waste disposal are needed to overcome this issue. Moreover, in Malaysia, the production of waste is more than 23,000 tonnes and expected to rise to 30,000 tonnes in 2020 [2]. Food waste is categorized as an organic solid waste because containing an enormous amount of organic matter, which eventually decay and generates carbon dioxide and methane. The common disposal method to dispose of organic waste is dumping it into the landfill has caused serious environmental pollution and health risks problems to living organisms [3].

In order to reduce the amount of solid wastes production, especially food waste, is one of the best methods that can be applied in the fermentation of organic waste into the eco 
enzyme. In this method, organic waste is converted into useful enzymes through the fermentation process. The enzyme produced, generally called a garbage enzyme or eco enzyme is known to have cleansing characteristics and has multi-functional applications as a multipurpose cleaner [1][4].

Generally, the aquaculture industry in the world has been growing enormously during the last 50 years. The current production from aquaculture industries is more than 50 million than in the early 1950s that less than a million tons [5][6]. As claimed by the Food and Agriculture Organization (FAO) of the United Nations, the production of the aquaculture industry in Malaysia rise from 150,000 tons in 2000 to 580,000 in 2010 [7]. The intensive development of the aquaculture industry has caused a major environmental pollution problem. The sludge (in slurry form) from aquaculture contains high nitrogenous compounds such as ammonia, nitrite and nitrate, phosphorus, and dissolved organic carbon, which causes serious environmental degradation [8]. The most economical way to treat the sludge from aquaculture is to discharge it into sedimentation ponds for 72 hours before releasing it into the rivers. However, studies show that sedimentation ponds were succeeded in reducing the suspended particulates but less effectual in reducing the nutrient concentrations [9]. This problem can be overcome by using an eco enzyme to treat the sludge discharge from aquaculture. Researchers recommended that this enzyme can be functioning to compose, decompose, catalysis, and transforms. It can be used as a low-cost alternative to enhance sludge quality by removing the impurities and bacteria, thus catalyst the process of waste back into the soil [6][10]. Eco enzymes seem to be the best alternative to induce the pre-treatment process of sludge with the better performance and less expensive compared to other chemical additives products that contain chemicals compounds and hazardous to human health or environment that demanding high energy and cost during the manufacturing process [4][10][11]. Thus, this study is conducted to produce and characterize eco enzymes from fruit waste fermentation and applied to the treatment of aquaculture sludge.

\section{Materials and Methods}

\subsection{Production of the eco enzyme.}

In order to prepare the eco enzyme, fruit and vegetable waste from pineapple, orange, tomato, and mango dregs, $300 \mathrm{~g}$ of brown sugar, and $3000 \mathrm{~g}$ of water are mixed together based on the following the ratio of 1: 3:10. After that, the enzyme mixture was placed in the air-tight plastic bottle and covered with aluminum foil and placed in a dark and cool place to prevent from the sunlight. During the first month of the fermentation process, gases were released daily to avoid rupturing due to the pressure built up in the container.

\subsection{Characterization of eco enzyme solution.}

After three months of fermentation, the enzyme was filtered to obtain the enzyme solution. Then laboratory test was conducted to determine the characteristic of the enzyme and the presence of its hydrolysis activities.

Characteristic of the eco enzyme a measured based on $\mathrm{pH}$, Total Solid (TS), Total Dissolved Solids (TDS), Biological Oxygen Demand (BOD), Chemical Oxygen Demand (COD), and it's enzyme activities, which is are Protease, Amylase, and Lipase were analyzed by using the method as listed in Table 1 . 
Table 1. Characterization method of Eco enzyme.

\begin{tabular}{l|l} 
Parameters & Method \\
\hline BOD & DO meter \\
\hline COD & Closed reflux method \\
\hline $\mathrm{pH}$ & pH meter \\
\hline TDS & Alpha Standard Methods 2540 C \\
\hline TS & Alpha Standard Methods 2540 B \\
\hline Lipase & Spectrophotometry \& Titrimetric Method \\
\hline Protease & $\begin{array}{l}\text { Titrimetric method Casein Digestion unit, } \\
\text { (CDU method) }\end{array}$ \\
\hline Amylase & 3,5-dinitrosalicyclic acid, (DNS method)
\end{tabular}

\subsection{Aquaculture sludge sampling.}

The sample of aquaculture sludge was collected from Qza freshwater farm, Wakaf Pelam, Kuala Terengganu (Malaysia). The characteristic of pure aquaculture sludge, such as Total Suspended Solid (TSS), Volatile Suspended Solids (VSS), Total Phosphorus (TP), Total Ammonia Nitrogen (TAN), and Chemical Oxygen Demand (COD) was analyzed before pretreatment.

\subsection{Pre-treatment process of aquaculture sludge using the eco enzyme.}

The effects and efficiency of eco-enzyme on the removal of pollutants in aquaculture sludge are measured based on TSS, TDS, COD, TAN and TP. The pre-treatment process was carried out for 10 days digestion period (Batch process). The dosage of eco enzyme used to treat the sludge varied into $5 \%, 10 \%$, and $15 \%$ dilution times, and the reading or data collection was taken once in two days.

\section{Results and Discussion}

\subsection{Characteristics of the eco enzyme.}

As shown in Table 2, the $\mathrm{pH}$ of the pure eco enzyme is 3.07 , which is in acidic condition because carbohydrate content in fruit and vegetable wastes turns into volatile acid, while the organic acid compound also leached out during the fermentation process [6]. The TDS and COD values of eco enzyme solution for this study are higher and BOD5 value is lower compared to the study by $[12,13]$.

Table 2. Characteristic of the eco enzyme.

\begin{tabular}{l|l|l} 
Parameter & Units & Value \\
\hline $\mathrm{pH}$ & - & 3.07 \\
\hline Total Dissolve Solid (TDS) & $\mathrm{mg} / \mathrm{l}$ & 15,900 \\
\hline Total Solid (TS) & $\mathrm{mg} / \mathrm{l}$ & $17,744.44$ \\
\hline $\begin{array}{l}\text { Biochemical Oxygen Demand } \\
\text { (BOD) }\end{array}$ & $\mathrm{mg} / \mathrm{l}$ & 87.53 \\
\hline $\begin{array}{l}\text { Chemical Oxygen Demand } \\
(\mathrm{COD})\end{array}$ & $\mathrm{mg} / \mathrm{l}$ & 133760
\end{tabular}

The study by [13] produced eco enzyme from fruit and vegetable peels mixed with jaggery and fermented for three months reported the value of TDS (2210 mg/l), COD (48200 $\mathrm{mg} / \mathrm{l})$, and $\mathrm{BOD}_{5}(1300 \mathrm{mg} / \mathrm{l})$. While the recent study by [13] that produced eco enzyme from a mixture of tomato, cauliflower, pineapple, orange, and mango dregs with molasses and water showed the value of TDS as $1040 \mathrm{mg} / \mathrm{l}, \mathrm{COD}$ as $158 \mathrm{mg} / \mathrm{l}$, and BOD5 as $79 \mathrm{mg} / \mathrm{l}$. However, the value of TS, TDS, COD, and BOD5 will decrease after being stored for a long time after filtered [14]. 


\subsection{Biocatalytic activities in the eco enzyme.}

Biocatalytic activities (Lipase, Amylase, and Protease) in eco enzyme solution were determined by altering the $\mathrm{pH}$ to $\mathrm{pH} 6,6.5,7,7.5$, and 8 , and the result is presented in Figure 1. The figure shows that the lipase activity in the enzyme solution increases dramatically when the $\mathrm{pH}$ reaches $\mathrm{pH} \mathrm{7,} \mathrm{pH} 7.5$, and $\mathrm{pH}$ 8. It is also observed that the maximum lipase activity is at $\mathrm{pH} 8$, and the lowest lipase activity is at $\mathrm{pH} 3.07$, which is the original $\mathrm{pH}$ of the eco enzyme solution. These results match the study by [15] state that the optimum of lipase activity is falling at $\mathrm{pH}$ range $7-10$ and will slowly drop if the $\mathrm{pH}$ increased until reach $\mathrm{pH} 12$. Therefore, in order to achieve the optimum lipase activity for mix eco enzyme, $\mathrm{pH}$ should be maintained in ranges from $\mathrm{pH} 7$ to $\mathrm{pH} 8$.

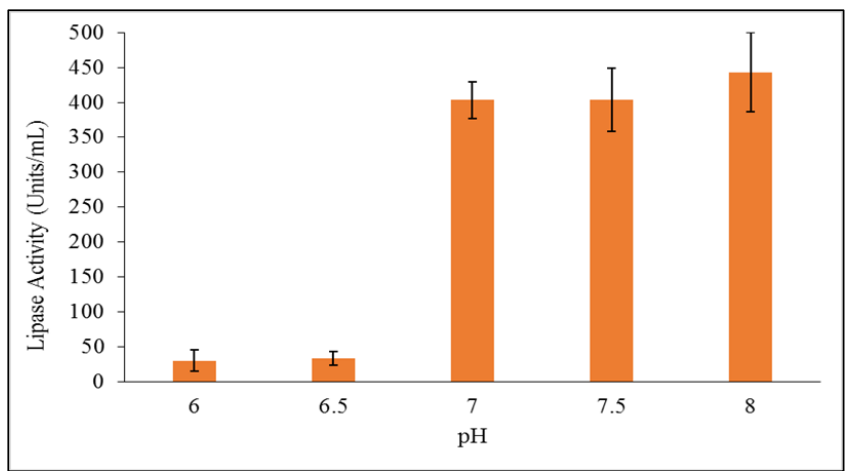

Figure 1. Lipase activity at different $\mathrm{pH}$.

Referring to the graph in Figure 2 shows that the optimum $\mathrm{pH}$ for amylase activity in the mixed eco enzyme is at $\mathrm{pH} 6.5$, and the lower amylase activity is at $\mathrm{pH} 3.07$, which is the original $\mathrm{pH}$ of the eco enzyme. The graph also shows Amylase activity gradually decreases when the $\mathrm{pH}$ changes to $\mathrm{pH} 7$ to $\mathrm{pH}$ 8. The results of this study for amylase activity are similar to the study by [13], which states that Amylase activity is very low in acidic conditions and increases in the basic $\mathrm{pH}$. The result presented in Figure 2 showed that the higher amylase activity of the mixed eco enzyme solution could be accomplished by sustaining the $\mathrm{pH}$ between the ranges 6.5 and 8 .

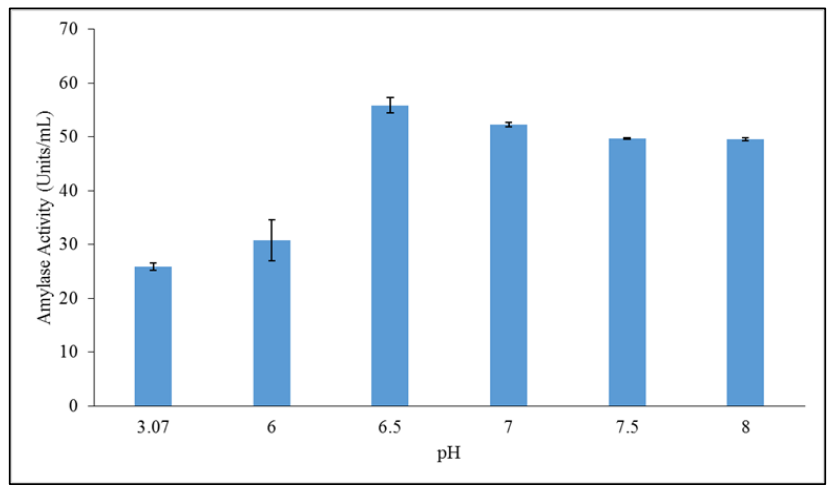

Figure 2. Amylase activity at different $\mathrm{pH}$.

Figure 3 , it is revealed that the highest protease activity is achieved at $\mathrm{pH} 6$, and the lowest protease activity is at $\mathrm{pH} 3.07$. Commonly, the $\mathrm{pH}$ value required to maximize the protease activity must be within the range $\mathrm{pH} 6$ up to $\mathrm{pH} 7$ [6]. From the graph in 3, it is specifying that the $\mathrm{pH}$ of the eco enzyme must be maintained at the range of $\mathrm{pH} 6-\mathrm{pH} 7$ to achieve the highest protease activity. 


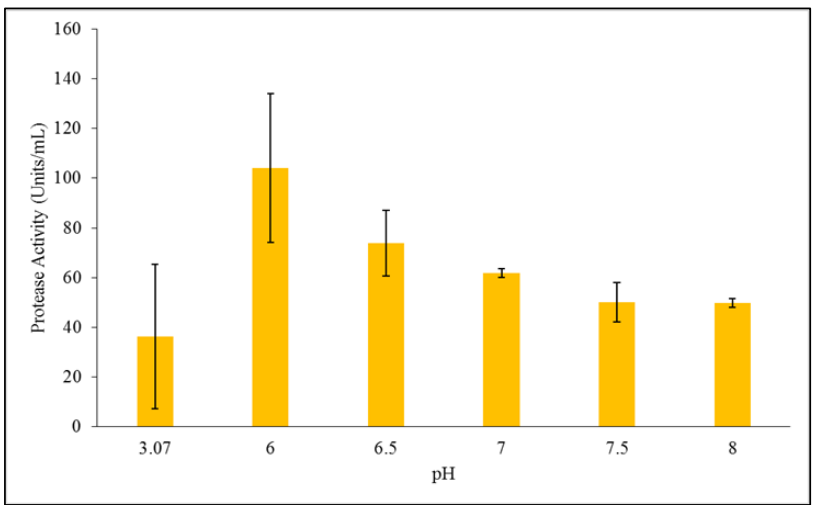

Figure 3. Protease activity at different $\mathrm{pH}$.

Based on the observation in Figure 1, Figure 2, and Figure 3, most of the biocatalytic activity (Lipase, Amylase, and Protease activity) are low in the acidic condition. As explained earlier in the study by [17], biocatalytic activity in the enzyme can be compromised by many environmental factors. For this study, the factor affecting the biocatalytic activity is $\mathrm{pH}$. Most of the biocatalytic activity a lost in acidic conditions because of $\mathrm{pH}$ affecting the hydrogen and ionic bonds in the enzyme solution, which are essential to enzyme activity and shape [18]. $\mathrm{pH}$ is used to measures the concentration of Hydrogen Ion $(\mathrm{H}+)$ and Hydroxide Ion (OH-). Lower $\mathrm{pH}$ signifies a higher concentration of $\mathrm{H}+$ and lowers concentrations of $\mathrm{OH}-$. When interference with Ionic and Hydrogen bonds that grip the enzyme happens, the bonding will be repelled or attracted by the other charges created from the bonds. This interruption causes a change in its active site and suppresses the enzymatic activity since most of the reaction occurs in the active site. Any interference in $\mathrm{pH}$ will affect biocatalytic activity [1]. Thus, this experiment proves that biocatalytic activities a presence in an eco enzyme solution and higher at $\mathrm{pH} 6.5$ compared to lower $\mathrm{pH}$.

\subsection{Efficiency of enzymatic pre-treatment on aquaculture sludge.}

The aquaculture sludge was characterized based on TSS, VSS, COD, TAN, TP parameters. The result of the pure aquaculture sludge is tabulated in Table 3.

Table 3. Characteristics of the pure aquaculture sludge.

\begin{tabular}{l|l|l} 
Parameters & Units & Value \\
\hline Total Suspended Solid (TSS) & $\mathrm{mg} / \mathrm{l}$ & 3066.67 \\
\hline Volatile Suspended Solid (VSS) & $\mathrm{mg} / \mathrm{l}$ & 988.89 \\
\hline $\begin{array}{l}\text { Chemical Oxygen Demand } \\
\text { (COD) }\end{array}$ & $\mathrm{mg} / \mathrm{l}$ & 64197.53 \\
\hline Total Ammonia Nitrogen (TAN) & $\mathrm{mg} / \mathrm{l}$ & 0.24 \\
\hline Total Phosphorus (TP) & $\mathrm{mg} / \mathrm{l}$ & 0.44
\end{tabular}

A batch test for ten days has been carried out to find out the effect of $5 \%, 10 \%$, and $15 \%$ dosage of the eco enzyme in treating aquaculture sludge. The effectiveness of the aquaculture sludge pre-treatment process can be determined using TSS and VSS reduction. The removal percentages of Total Suspended Solids and Volatile Solids from aquaculture sludge pre-treatment with a different dilution factor of the eco enzyme $(5 \%, 10 \%, 15 \%)$ are presented in Figure 4 and Figure 5, respectively.

From the observation, it is showed that the removal percentage of TSS and VSS in aquaculture sludge increased gradually with time when digested with $5 \%, 10 \%$, and $15 \%$ dilution factors of the mixed eco enzyme. 


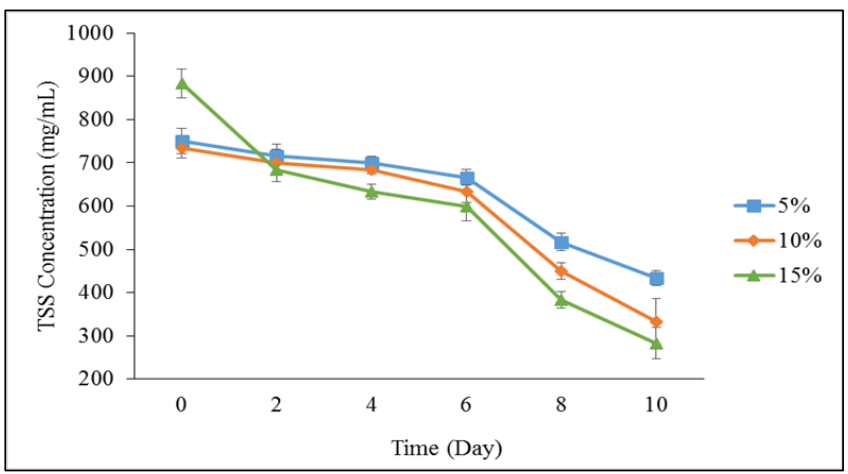

Figure 4. TSS removal in aquaculture sludge and treatment for a different dosage of the eco enzyme $(5 \%, 10$ $\%$, and $15 \%$ ) for 10 days.

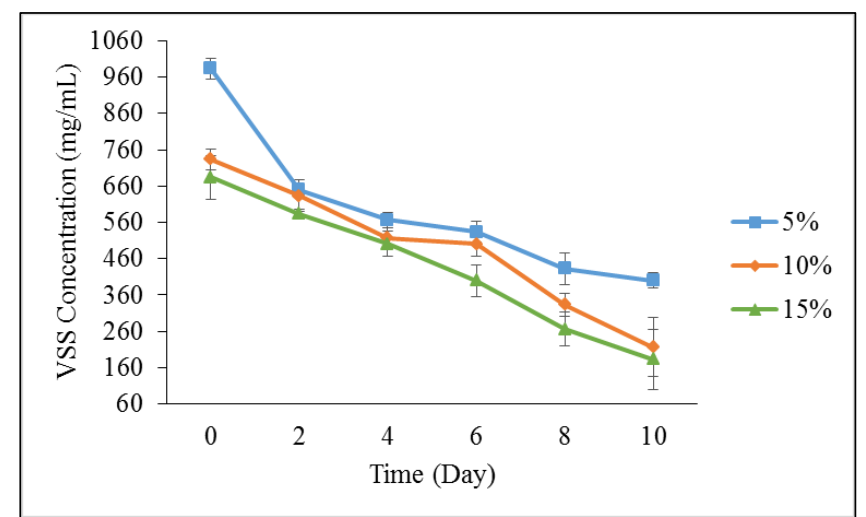

Figure 5. VSS removal in aquaculture sludge and treatment for a different dosage of the eco enzyme (5\%, 10 $\%$, and $15 \%$ ) for 10 days.

From the graph, we can see that the eco enzyme with a $15 \%$ dilution factor is more effective in removing the TSS and VSS than $5 \%$ and $10 \%$ dilution factors. However, the rate of removal between $10 \%$ and $15 \%$ is not significantly different from one another. The aquaculture sludge treated with $15 \%$ dosage of eco enzyme collected after 10 days showed $283 \mathrm{mg} / \mathrm{mL}$ and $183 \mathrm{mg} / \mathrm{mL}$ concentration of TSS and VSS respectively, $10 \%$ eco enzyme showed $333 \mathrm{mg} / \mathrm{mL}$ and $217 \mathrm{mg} / \mathrm{mL}$ concentration of TSS and VSS respectively and $5 \%$ eco enzyme reported $433 \mathrm{mg} / \mathrm{mL}$ and $400 \mathrm{mg} / \mathrm{mL}$ concentration of TSS and VSS respectively.

Therefore it is clear that mix eco enzyme has the ability to remove TSS and VSS in aquaculture sludge. The result of the TSS and VSS reduction for this study is comparable with the research reported by [19], stated that protease had the greatest influence in improving aquaculture sludge settle-ability. Another finding by [20] claimed that enzyme treatment on sludge able to catalyst the anaerobic digestion, thus solubilize the sludge solids because of the breakdown process of the larger organic particulate matter into smaller particles and will increase the availability of surface area for the bacteria that responsible for degradation. A recent study reported by [15] also supports the possibility that these high TSS \& VSS removal percentage results are caused by the biocatalytic activity that presence in eco enzyme and have an influence on aquaculture sludge solubilization. Moreover, citric acid in the eco enzyme also has the capability to catalyst the sludge breakage, which results in higher removal of TSS and VSS when aquaculture sludge was treated with the mixed eco enzyme [5,21].

Increasing the availability of biodegradable and biodegradability of organic matter is a key objective in the treatment of aquaculture sludge. Therefore, COD stabilization is considered a very important parameter for assessing the effectiveness of the eco enzyme [5]. 
Thus, the result of the COD reduction during the pre-treatment process of the aquaculture sludge is presented in Figure 6.

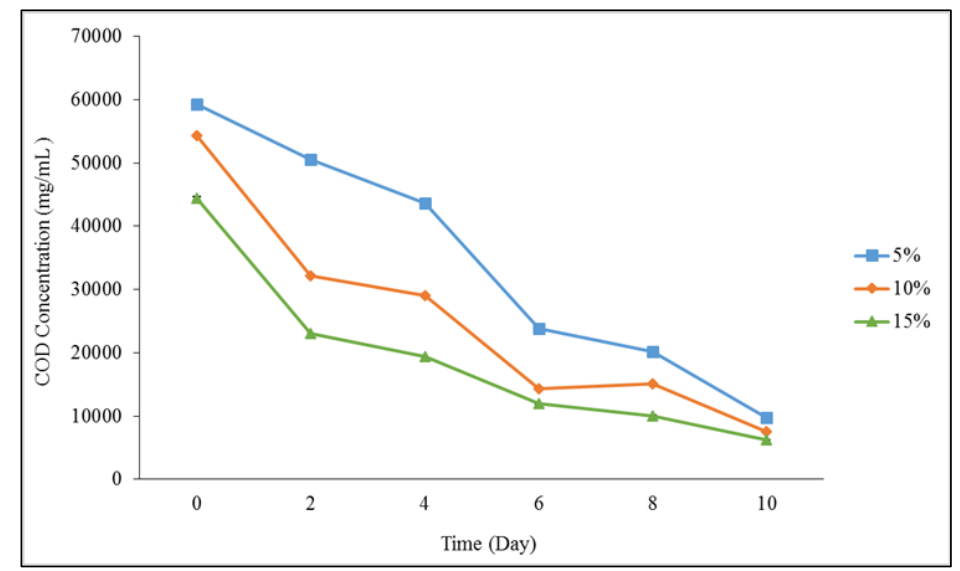

Figure 6. COD removal in aquaculture sludge and treatment for different dosage of the eco enzyme $(5 \%, 10 \%$, and $15 \%$ ) for 10 days.

From the graph in 6 above, we can see that the removal percentage of Chemical Oxygen Demand significantly increases when pre-treatment time was increased. Further analysis showed that after the tenth days of pre-treatment, the removal rate of $15 \%$ dilution factor was higher than $10 \%$ and $5 \%$ dosage of the eco enzyme where the $15 \%$ eco enzyme showed the COD concentration was $6222 \mathrm{mg} / \mathrm{mL}, 10 \%$ eco enzyme was $7556 \mathrm{mg} / \mathrm{mL}$ and $5 \%$ eco enzyme was $9778 \mathrm{mg} / \mathrm{mL}$.

The high rate of COD reduction in aquaculture sludge means the biocatalytic activities contained in in mix eco enzyme has acted as a catalysts agent in the hydrolysis process, then the reduction of COD concentration occurred through the alteration of its molecular structure $[22,23]$. COD reduction also an indication that the aquaculture sludge contains a large number of soluble substances, and when the organic particles are solubilized, it can be readily degraded by microorganisms during anaerobic digestion processing to produce biogas [13, 24, 25].

The result of this study shows the similarity with previous research by [20, 26] that study on the impact of the hydrolytic enzymes on sludge degradation reported that TSS and VSS reduction with COD removal are closely related. This is stemming from the breakdown process on sludge solid that accelerated by enzymatic activities into smaller particle sizes has been improved the digestion process and lead to the increased yield of methane, thus decreases the residual COD in sludge $[27,28]$.

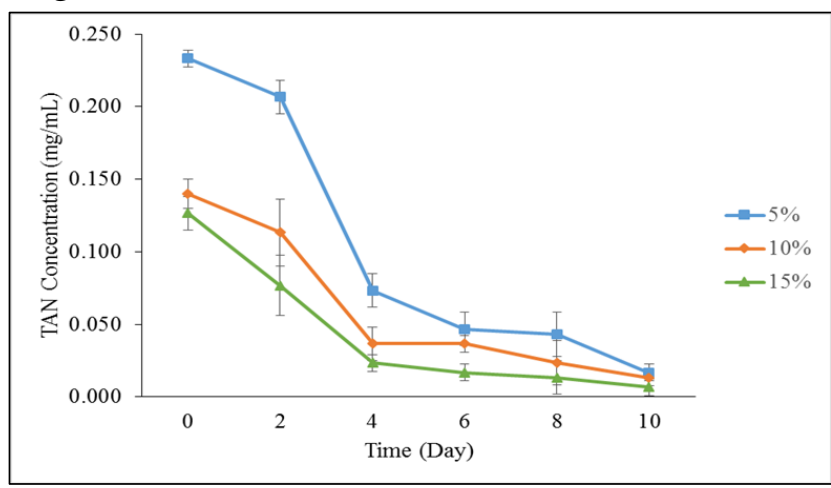

Figure 7. TAN removal in aquaculture sludge and treatment for different dosage of the eco enzyme $(5 \%, 10 \%$, and $15 \%$ ) for 10 days. 
Aquaculture sludge contains an enormous number of nitrogenous compounds in the form of Total Ammonia Nitrogen and Total Phosphorus as a result of high nutrients from feces and uneaten food [29]. The removal percentages of Total Ammonia Nitrogen and Total Phosphorus from aquaculture sludge pre-treatment with a different dilution factor of the eco enzyme $(5 \%, 10 \%, 15 \%)$ are illustrated in Figure 7 and Figure 8, respectively.

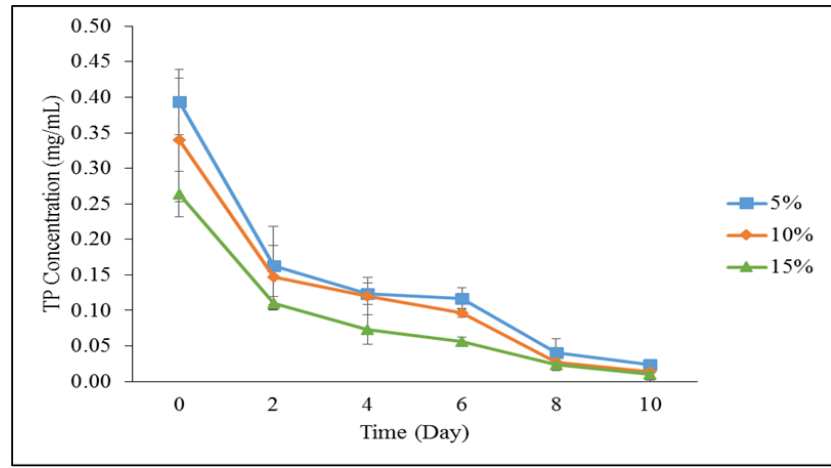

Figure 8. TP removal in aquaculture sludge and treatment for a different dosage of the eco enzyme $(5 \%, 10 \%$, and $15 \%$ ) for 10 days.

As shown in Figures 7 and 8, the removal rate of Total Ammonia Nitrogen and total phosphorus increasing sharply with the digestion time. From the observation, the removal rates of TAN and TP with $15 \%$ eco enzyme are reported significantly higher than $10 \%$ and $5 \%$. The aquaculture sludge treated with $15 \%$ dosage of eco enzyme collected after 10 days showed $0.007 \mathrm{mg} / \mathrm{mL}$ and $0.010 \mathrm{mg} / \mathrm{mL}$ concentration of TAN and TP respectively, $10 \%$ eco enzyme showed $0.013 \mathrm{mg} / \mathrm{mL}$ and $0.013 \mathrm{mg} / \mathrm{mL}$ concentration of TAN and TP respectively and $5 \%$ eco enzyme reported $0.023 \mathrm{mg} / \mathrm{mL}$ and $0.017 \mathrm{mg} / \mathrm{mL}$ concentration of TAN and TP respectively.

Removal of Total Ammonia Nitrogen and Total Phosphorus in aquaculture sludge by using the eco enzyme is caused by the existence of organic acid as a carbon source and biocatalytic activities in eco enzyme solution, which helped in the breakdown process of the insoluble form of minerals into the soluble form [7,30,31].

A study by [18] reported a similar finding when studying the solubilization of Total Phosphorus in waste activated sludge using the eco enzyme. A recent study by [32-34] also states a similar result when investigating the removal of Ammonia Nitrogen and Phosphate in the treatment of greywater using an eco enzyme that is produced from fruit and vegetable peels.

\section{Conclusions}

The findings from this study confirm that enzymatic activities, which are lipase, protease, amylase, are the presence in mixed eco enzyme contained a high concentration of TS, TDS, COD \& BOD. From the result of the pre-treatment process on aquaculture sludge in ten days (Batch process), it was found out that the eco enzyme solution is very efficient in removal of Total Suspended Solid (TSS), Volatile Suspended Solids (VSS), Total Phosphorus (TP) Total Ammonia Nitrogen (TAN) and stabilization of the Chemical Oxygen Demand (COD). The results significantly showed that the most efficient and economic concentration of the eco enzyme is $10 \%$ dilution times and reported with $89 \%$ removal percentage of TSS, $78 \%$ removal percentage of VSS, $88 \%$ reduction percentage of COD, $94 \%$ removal percentage of TAN and $97 \%$ removal percentage of TP. Therefore, the finding of this study can be used to reduce the composition of organic waste in Municipal Solid Waste in Malaysian, and at the same time, 
production of the eco enzyme can be used as an additive to treat aquaculture sludge with low cost and environmental friendly.

\section{Funding}

This research was funded by the Fundamental Research Grant Scheme (FRGS-Vot. No. 59437), Ministry of Higher Education Malaysia.

\section{Acknowledgments}

The authors wish to thank and acknowledge the Fundamental Research Grant Scheme (FRGSVot. No. 59437), Ministry of Higher Education Malaysia for the financial support, and Universiti Malaysia Terengganu for its assistance provided during the course of this study. The authors wish to thank and acknowledge the Ministry of Higher Education Malaysia for the financial support and Universiti Malaysia Terengganu for its assistance provided during the course of this study

\section{Conflicts of Interest}

The authors declare no conflict of interest. The funders had no role in the design of the study; in the collection, analyses, or interpretation of data; in the writing of the manuscript, or in the decision to publish the results.

\section{References}

1. Ho, Y.M., Ling, L.K.; Latifah A.M. Garbage Enzyme as a Solution to Waste. From Sources to Solution. Publisher: Springer, Singapore, 2014; pp. 347-350, https://doi.org/10.1007/978-981-4560-70-2_63.

2. Murphy, S. General Information on Solids. Retrieved from Boulder Area Sustainability Information Network. Retrieved on 23 January 2020.

3. Ferronato, N.; Torretta, V. Waste Mismanagement in Developing Countries: A Review of Global Issues. International Journal of Environmental Research and Public Health 2019, 16, 1-28, https://doi.org/10.3390/ijerph16061060.

4. Verma, D.; Singh, A.N.; Shukla, A.K. Use of Garbage Enzyme for Treatment of Waste Water. International Journal of Scientific Research and Review 2019, 7, 201-205.

5. Mikawlrawng, K. Aspergillus in Biomedical Research. INew and Future Developments in Microbial Biotechnology and Bioengineering. 2016; pp. 221-234.

6. Gómez, S.; Hurtado, C.F.; Orellana, J. Bioremediation of organic sludge from a marine recirculating aquaculture system using the polychaete Abarenicola pusilla (Quatrefages, 1866). Aquaculture 2019, 507, 377-384, https://doi.org/10.1016/j.aquaculture.2019.04.033.

7. Food and Agricultural Organization of the United Nations (FAO). National Aquaculture Sector Overview: Malaysia. Retrieved on 3 March 2020; http://www.fao.org/fishery/countrysector/naso_malaysia/en.

8. Manios, T.; Stentiford, E.I.; Millner, P.A. The removal of NH3-N from primary treated wastewater in subsurface reed beds using different substrates. Journal of Environmental Science and Health, Part A 2002, 37, 297-308, https://doi.org/10.1081/ESE-120002829.

9. Nobuyuki, K.; Kushairi, M.R.M.; Nagao, N.; Fatimah, Y.; Akio. I.; Ayato, K. Release of Nitrogen and Phosphorus from Aquaculture Farms to Selangor River, Malaysia. International Journal of Environmental Science and Development 2016, 7, 113-116, https://doi.org/10.7763/IJESD.2016.V7.751.

10. Ng, H.S.; Kee, P.E.; Yim, H.S.; Chen, P.-T.; Wei, Y.-H.; Chi-Wei Lan, J. Recent advances on the sustainable approaches for conversion and reutilization of food wastes to valuable bioproducts. Bioresource Technology 2020, 302, https://doi.org/10.1016/j.biortech.2020.122889.

11. Sharma, P.; Gaur, V.K.; Kim, S.-H.; Pandey, A. Microbial strategies for bio-transforming food waste into resources. Bioresource Technology 2020, 299, https://doi.org/10.1016/j.biortech.2019.122580.

12. Department of Environment, Malaysia. Malaysia Marine Water Quality Criteria and Standard (MMWQCS).

13. Arun, C.; Sivashanmugam, P. Investigation of biocatalytic potential of garbage enzyme and its influence on stabilization of industrial waste activated sludge. Process Safety and Environmental Protection 2015, 94, 471-478, https://doi.org/10.1016/j.psep.2014.10.008. 
14. Nazim, F.; Meera, V. Treatment of synthetic greywater using 5\% and $10 \%$ garbage enzyme solution. Bonfring International Journal of Industrial Engineering and Management Science 2013, 3, 111-117, https://doi.org/10.9756/BIJIEMS.4733.

15. Crawford, C.M. Environmental risk assessment of shellfish farming in Tasmania. Tasmanian Aquaculture and Fisheries; Institute: University of Tasmania 2001.

16. Ottinger, M.; Clauss, K.; Kuenzer, C. Aquaculture: Relevance, distribution, impacts and spatial assessments - A review. Ocean \& Coastal Management 2016, 119, 244-266, https://doi.org/10.1016/j.ocecoaman.2015.10.015.

17. Eed, J. Factors Affecting Enzyme Activity. ESSAI 2012, 10.

18. Arun, C.; Sivashanmugam, P. Solubilization of waste activated sludge using a garbage enzyme produced from different pre-consumer organic waste. RSC Advances 2015, 5, 51421-51427, https://doi.org/10.1039/C5RA07959D.

19. Parmar, N.; Singh, A.; Ward, O.P. Enzyme treatment to reduce solids and improve settling of sewage sludge. Journal of Industrial Microbiology and Biotechnology 2001, 26, 383-386, https://doi.org/10.1038/sj.jim.7000150.

20. Roman, H.J.; Burgess, J.E.; Pletschke, B.I. Enzyme treatment to decrease solids and improve digestion of primary sewage sludge. African Journal of Biotechnology 2006, 5, 963-967.

21. Sadh, P.K.; Duhan, S.; Duhan, J.S. Agro-industrial wastes and their utilization using solid state fermentation: a review. Bioresources and Bioprocessing 2018, 5, 1-15, https://doi.org/10.1186/s40643-017-0187-z.

22. Bharagava, R.N.; Chowdhary, P. Emerging an Eco-Friendly Approaches for Waste Management. 2019. Springer Nature, Singapore. https://doi.org/10.1007/978-981-10-8669-4.

23. Singh, R.L; Singh, R.P. Advances in Biological Treatment of Industrial Wastewater and their Recycling for Sustainable Future. 2019. Springer Nature, Singapore. https://doi.org/10.1007-978-981-13-1468-1.

24. Gallert, C.; Winter, J.U. Bacterial Metabolism in Wastewater Treatment Systems. In: Environmental Biotechnology: Concepts and Applications. Wiley, Weinheim. 2005; https://doi.org/10.1002/3527604286.ch1.

25. Kamaruddin, M.A.; Ibrahim, M.H.; Thung, L.M.; Emmanuel, M.I.; Niza, N.M.; Shadi, A.M.H.; Norashiddin, F.A. Sustainable synthesis of pectinolytic enzymes from citrus and Musa acuminata peels for biochemical oxygen demand and grease removal by batch protocol. Applied Water Science 2019, 9, 1-10, https://doi.org/10.1007/s13201-019-0948-2.

26. Tongco, J.V.; Kim, S.; Oh, B.-R.; Heo, S.-Y.; Lee, J.; Hwang, S. Enhancement of Hydrolysis and Biogas Production of Primary Sludge by Use of Mixtures of Protease and Lipase. Biotechnology and Bioprocess Engineering 2020, 25, 132-140, https://doi.org/10.1007/s12257-019-0302-4.

27. Neupane, K.; Khadka, R. Production of Garbage Enzyme from Different Fruit and Vegetable Wastes and Evaluation of its Enzymatic and Antimicrobial Efficacy. Tribhuvan University Journal of Microbiology 2019, 6, 113-118, https://doi.org/10.3126/tujm.v6i0.26594.

28. Oladejo, J. ; Shi, K.; Luo, X.; Yang, G.; Wu, T. A Review of Sludge-to-Energy Recovery Methods. Energies, 2019, 12, 60, https:doi.org/10.3390/en12010060.

29. Nabarlatz, D.; Vondrysova, J.; Jenicek, P.; Stüber, F.; Font, J.; Fortuny, A.; Bengoa, C. Hydrolytic enzymes in activated sludge: Extraction of protease and lipase by stirring and ultrasonication. Ultrasonics Sonochemistry 2010, 17, 923-931, https://doi.org/10.1016/j.ultsonch.2010.02.006.

30. Puigagut, J.; Angles, H.; Chazarenc, F.; Comeau, Y. Decreasing phosphorus discharge in fish farm ponds by treating the sludge generated with sludge drying beds. Aquaculture 2011, 318, 7-14, https://doi.org/10.1016/j.aquaculture.2011.04.025.

31. Elsamadony, M. Enrich waste activated sludge digestibility via natural enzyme supplementation. E3S Web of Conferences, 2019, 83, 01012. https://doi.org/10.1051/e3sconf/20198301012.

32. Malila, R.; Lehtoranta, S.; Viskari, E.L. The role of source separation in nutrient recovery-Comparison of alternative wastewater treatment systems. Journal of Cleaner Production 2019, 219, 350-358. https://doi.org/10.1016/j.jclepro.2019.02.024.

33. Fazna, N.; Meera, V. Treatment of Greywater using Garbage Enzymes. Bonfring International Journal of Industrial Engineering and Management Science 2013, 3, 241-244.

34. Kumar, A., Sadhya, H.K., Ahmad, E. and Dulawat, S. Application of Bio-Enzyme in Wastewater (Greywater) Treatment. International Research Journal of Engineering and Technology 2020, 7, 2886-2890. 